\title{
Role of the local bone renin-angiotensin system in steroid-induced osteonecrosis in rabbits
}

\author{
YONGTAO ZHANG ${ }^{1}$, KUNZHENG WANG $^{1}$, QICHUN SONG ${ }^{1}$, RUIYU LIU ${ }^{1}$, \\ WENCHEN JI ${ }^{2}$, LE JI ${ }^{1}$ and CHUNSHENG WANG ${ }^{1}$ \\ ${ }^{1}$ Department of Orthopaedics, The Second Affiliated Hospital of Xi'an Jiaotong University, Xi'an, Shaanxi 710004; \\ ${ }^{2}$ Medical College of Xi'an Jiaotong University, Xi'an, Shaanxi 710061, P.R. China
}

Received August 5, 2013; Accepted February 11, 2014

DOI: $10.3892 / \mathrm{mmr} .2014 .1978$

\begin{abstract}
The specific pathogenesis of steroid-induced osteonecrosis (ON) is yet to be elucidated and until recently effective prophylactic therapies have not been available. The local renin-angiotensin system (RAS) exists in the bone and has an important role in local bone regulation. However, to the best of our knowledge, the interrelation between local bone RAS and steroid-induced $\mathrm{ON}$ is yet to be investigated. In the present study, 45 rabbits were injected with a single intramuscular dose of $20 \mathrm{mg} / \mathrm{kg}$ methylprednisolone acetate (MPA) and were sacrificed 1 (group A), 2 (group B) and 3 (group C) weeks subsequent to MPA administration ( $n=15$ per group). Ten rabbits were used as a control group (group N). The presence or absence of $\mathrm{ON}$ in the bilateral femoral heads was examined histopathologically. The mRNA and protein expression of components of the RAS, including angiotensin II (Ang II), angiotensin converting enzyme (ACE) and Ang II type 1 $\left(\mathrm{AT}_{1}\right)$ and Ang II type $2\left(\mathrm{AT}_{2}\right)$ receptors, were detected in the bone. Significant changes in Ang II, ACE, and $\mathrm{AT}_{1}$ and $\mathrm{AT}_{2}$ receptor expression were observed in the bone of the rabbits in the different groups. Moreover, the expression of Ang II and ACE was highest one week subsequent to administration of the glucocorticoid methylprednisolone and the expression of the $\mathrm{AT}_{1}$ and $\mathrm{AT}_{2}$ receptors was highest two weeks following methylprednisolone administration. ON occurs most significantly at three weeks following the administration of MPA in this animal model, thus the changes in Ang II, ACE and $\mathrm{AT}_{1}$ and $\mathrm{AT}_{2}$ receptor expression preceded this. The present study
\end{abstract}

Correspondence to: Professor Chunsheng Wang or Professor Kunzheng Wang, Department of Orthopaedics, The Second Affiliated Hospital of Xi'an Jiaotong University, Xi'an, Shaanxi 710004, P.R. China

E-mail:wcs420@163.com

E-mail: drkunzhengwang@126.com

Key words: bone metabolism, bone microcirculation, rabbit, renin-angiotensin system, osteonecrosis, steroid found that ON was strongly associated with the activation of the local bone RAS in rabbits.

\section{Introduction}

Osteonecrosis $(\mathrm{ON})$ is one of the most serious complications induced by high doses and/or long-term administration of glucocorticoids (GCs). Several mechanisms have been associated with the pathogenesis of $\mathrm{ON}$, including intraosseous hypertension, oxidation injury, apoptosis, hypercoagulability and lipid metabolism disorders (1-5). However, the precise mechanism underlying the pathogenesis of steroid-induced $\mathrm{ON}$ is yet to be elucidated and until recently, effective prophylactic therapies have not been available.

The renin-angiotensin system (RAS) is classically known to be a circulating endocrine system regulating blood pressure and electrolyte homeostasis. The main effector peptide in RAS is angiotensin (Ang) II, which is formed from Ang I by angiotensin-converting enzyme (ACE). Ang II exerts its biological effects through binding to specific angiotensin receptors, primarily the Ang II type $1\left(\mathrm{AT}_{1}\right)$ receptor. In addition to this classical systemic RAS, additional local tissue-specific RASs have been identified in various organs and tissues, including the heart, kidney, bone marrow, blood vessels and fat tissues. Moreover, the local RAS has been identified to have an important role in local organ regulation (6).

The local RAS has been shown to exist in bone tissue $(7,8)$ and its activation in bone tissue has been found to induce metabolic bone disorders (9-11). Furthermore, Ang II-induced signaling in vascular and endothelial cells promotes reactive oxygen species (ROS) production, platelet activation, inflammation and altered vasoreactivity, all of which impair bone microcirculation (12).

Previous studies have shown that GCs stimulate ACE expression in bovine aorta endothelial cells, rat cardiac fibroblasts and vascular smooth muscle cells (13-15). Furthermore, Sato et al (16) showed that GCs upregulate the expression of the $\mathrm{AT}_{1}$ receptor in vascular smooth muscle cells. However, little is known about the role of GCs in the regulation of the RAS in the bone.

In the present study, it was hypothesized that GCs may activate the local bone RAS and that this activation may be involved in the pathogenesis of steroid-induced ON. Therefore, 
this study investigated the effect of steroid-induced $\mathrm{ON}$ on the expression of Ang II, ACE and $\mathrm{AT}_{1}$ and Ang II type $2\left(\mathrm{AT}_{2}\right)$ receptors in adult female Japanese white rabbits.

\section{Materials and methods}

Animals. The experimental protocol was approved by the institutional animal use and care review board of Xi'an Jiaotong University (Xi'an, China). Fifty-five adult, female Japanese white rabbits (weight, 3.3-4.2 kg; age, 30-32 weeks; Animal Center of Xi'an Jiaotong University) were investigated. All rabbits were housed at the Animal Center of Xi'an Jiaotong University and maintained on a standard diet and water.

Forty-five rabbits were injected once with $20 \mathrm{mg} / \mathrm{kg}$ body weight methylprednisolone acetate (MPA; Pfizer, Inc., Brussels, Belgium) into the right gluteal muscle, and were then divided into three groups (A, B and C) consisting of 15 rabbits per group. The rabbits in groups $\mathrm{A}, \mathrm{B}$ and $\mathrm{C}$ were sacrificed by overdose of anesthesia at 1,2 and 3 weeks subsequent to MPA administration, respectively. The control group (group N) consisted of 10 rabbits, which were maintained under the same conditions as the treatment groups, but were not injected with MPA (17). Immediately following sacrifice, one half of each femoral head was isolated and fixed in $10 \%$ neutral buffered formalin, decalcified using 13\% EDTA and embedded in paraffin. The other half of each femoral head was frozen and stored at $-80^{\circ} \mathrm{C}$ for additional examinations.

Assessment of $O N$. One 4- $\mu \mathrm{m}$ thick section of each femoral head was cut in the coronal plane and stained with hematoxylin and eosin. The presence or absence of ON was determined in whole areas of two sections for each rabbit. The sections were examined using light microscopy (Nikon YS100; Nikon Corporation, Toyko, Japan) by two blinded pathologists. ON was identified based on the presence of empty lacunae or pyknotic osteocyte nuclei in the bone trabeculae, as well as the presence of necrosis in the surrounding bone marrow or fat cells. Empty lacunae in the bone trabeculae, but without bone marrow or fat cell necrosis was not classified as ON (Fig. 1). Rabbits were considered to have $\mathrm{ON}$ based on the identification of $\mathrm{ON}$ in at least one of the two sections analyzed. The incidence of $\mathrm{ON}$ was calculated as the ratio of the number of rabbits with $\mathrm{ON}$ to the total number of rabbits $(17,18)$.

Immunohistochemistry. Immunohistochemistry was performed using one 4- $\mu \mathrm{m}$ thick section of each femoral head in order to assess the presence of $\mathrm{AT}_{1}$ receptors and $\mathrm{ACE}$ using specific antibodies according to the manufacturer's instructions. Briefly, subsequent to deparaffinization, sections were treated with $3 \%$ hydrogen peroxide for $20 \mathrm{~min}$ to inhibit endogenous peroxidase activity. Antigen retrieval was then performed using $0.01 \mathrm{M}$ citrate buffer ( $\mathrm{pH} 6.0$ ) at $80^{\circ} \mathrm{C}$ for $10 \mathrm{~min}$. Sections were preincubated with normal goat serum (Biosynthesis Biotechnology Co. Ltd., Beijing, China) for $30 \mathrm{~min}$ at room temperature, prior to incubation at $4^{\circ} \mathrm{C}$ overnight with mouse anti-rabbit ACE (ab11734; Abcam PLC, Cambridge, MA, USA) and $\mathrm{AT}_{1}$ receptor (ab9391; Abcam PLC) monoclonal antibodies, diluted 1:20 and 1:50 in phosphate-buffered saline, respectively. Sections were then incubated with secondary goat anti-mouse antibodies (Biosynthesis Biotechnology Co. Ltd.) and with horseradish peroxidase (HRP)-labeled streptavidin (Biosynthesis Biotechnology Co. Ltd.). The final reaction product was visualized using diaminobenzidine. Images were captured using the QWin550CW Image Acquiring and Analysis system (Leica Microsystems, Wetzlar, Germany). Heart tissue was used as a positive control and showed positive brown staining. Sections without primary antibody-treatment were used as negative controls.

The intensity of $\mathrm{AT}_{1}$ receptor and $\mathrm{ACE}$ immunostaining in groups $\mathrm{N}, \mathrm{A}, \mathrm{B}$ and $\mathrm{C}$ were quantitatively analyzed using the analysis software Image-Pro Plus (Media Cybernetics, Baltimore, MD, USA). One section was obtained from each rabbit and 10 images were captured from each section, which were analyzed for positive staining at a magnification of $\mathrm{x} 400$. The total area of each analyzed section was the same. Integrated optical density (IOD) was assessed, in which 'integrated' refers to the sum of all the pixel intensity or density values in a given image. The IOD values obtained from the 10 images in each section were averaged and compared with the averaged IOD values of each section.

Western blot analysis. Six femoral heads were selected randomly from each group for western blot analysis. Total protein was isolated by homogenizing the femoral head using radioimmunoprecipitation assay buffer (RIPA) buffer. The concentration of total protein was quantified using the bicinchoninic acid (BCA) protein assay reagent $\left(\right.$ Pierce $^{\mathrm{TM}}$, Rockford, IL, USA). Laemmli buffer (5X) was added to each sample to a final concentration of $1 \mathrm{X}$, and $20 \mu \mathrm{l}$ of each preparation was loaded onto 5 and $10 \%$ SDS polyacrylamide gels. SDS-PAGE was performed using a constant voltage of $90 \mathrm{~V}$ for $100 \mathrm{~min}$. Following electrophoresis, proteins were transferred onto $0.45 \mu \mathrm{m}$ nitrocellulose and polyvinylidene fluoride membranes (Hybond-ECL; Amersham Pharmacia Biotechnology Inc., Piscataway, NJ, USA) and blocked with $3 \%$ bovine serum albumin at room temperature for $2 \mathrm{~h}$. Membranes were incubated overnight at $4^{\circ} \mathrm{C}$ with anti-AT receptor and -ACE primary antibodies (Abcam PLC) diluted 1:400 and 1:100, respectively. Membranes were then incubated with HRP-labeled goat anti-mouse secondary antibodies (Santa Cruz Biotechnology, Inc., Santa Cruz, CA, USA). Immunoreactive proteins were visualized on a film using an enhanced chemiluminescence kit (NEN Life Science Products Inc., Boston, MA, USA). Relative protein expression was determined using image analysis software (Media Cybernetics). $\beta$-actin was detected using a mouse monoclonal anti-actin antibody (1:3,000; Santa Cruz Biotechnology, Inc.) and was used as an internal control.

Analysis of ACE activity in the serum and bone. Prior to sacrifice, blood was collected from all rabbits without anticoagulant and was stored on ice. Blood was then centrifuged at $1,848 \mathrm{x}$ g for $10 \mathrm{~min}$. The serum was obtained and stored at $-80^{\circ} \mathrm{C}$ until required for the ACE assay. A total of $200 \mathrm{mg}$ bone tissue was obtained from each rabbit and homogenized in ice-cold Tris- $\mathrm{HCl}$ buffer solution $(1 \mathrm{ml} / 100 \mathrm{mg}$ sample wet weight). The buffer solution consisted of $20 \mathrm{mM}$ Tris- $\mathrm{HCl}$ (pH 8.3), $5 \mathrm{mM} \mathrm{Mg}(\mathrm{CH} 3 \mathrm{COO})_{2}, 30 \mathrm{mM} \mathrm{KCl}, 250 \mathrm{mM}$ sucrose and $0.5 \%$ Nonidet P-40. The homogenized samples were centrifuged for $30 \mathrm{~min}$ at $11,300 \mathrm{x} \mathrm{g}$ at $4^{\circ} \mathrm{C}$. The protein 
concentration in the supernatant was quantified using the BCA protein assay reagent (Pierce). The supernatant was stored at $-80^{\circ} \mathrm{C}$ until required for the ACE assay.

ACE activity in the serum and the supernatant was determined by analyzing the production rate of hippuric acid from the synthetic tripeptide substrate hippuryl-L-histidyl-L-leucine (HHL) as described previously (19). The serum and the supernatant were incubated with the substrate, HHL, and the hippuric acid concentration was assessed using ultra violet absorbance at $228 \mathrm{~nm}$. ACE activity was expressed as $\mathrm{nmol} / \mathrm{min} / \mathrm{mg}$ protein or per $\mathrm{ml}$ serum. All analyses were performed in duplicate.

Analysis of Ang II concentration in the plasma and bone. Prior to sacrifice, blood was collected from all rabbits with a mixture of protease inhibitors (0.30 M EDTA, 0.32 M dimercaprol dimercaptopropanol and 0.34 M 8-sulfhydryl quinoline sulfate) and stored on ice. Blood was then centrifuged at $943 \mathrm{x} \mathrm{g}$ for $7 \mathrm{~min}$. The plasma was obtained and stored at $-80^{\circ} \mathrm{C}$ until required for the Ang II assay. A total of $100 \mathrm{mg}$ bone tissue was obtained from each rabbit and homogenized and extracted in lysis buffer containing $10 \mathrm{mM}$ Tris, $\mathrm{pH} 7.5$, $10 \mathrm{mM} \mathrm{NaCl}, 0.1 \mathrm{mM}$ EDTA, $0.5 \%$ Triton X-100, 0.02\% $\mathrm{NaN}_{3}$ and $0.2 \mathrm{mM}$ phenylmethylsulfonyl fluoride protease inhibitor cocktail. The homogenized samples were then centrifuged for $30 \mathrm{~min}$ at $11,300 \mathrm{x} \mathrm{g}$ at $4^{\circ} \mathrm{C}$. The protein concentration in the supernatant was quantified using the BCA protein assay reagent (Pierce). The supernatant was stored at $-80^{\circ} \mathrm{C}$ until required for the Ang II assay. The concentration of Ang II was measured using radioimmunoassay (RIA) (20) with a commercial RIA kit (Beifang, Tianjin, China). The concentration of Ang II was expressed as $\mathrm{pg} / \mathrm{mg}$ protein or $\mathrm{pg} / \mathrm{ml}$ plasma. All analyses were performed in duplicate.

Quantitative polymerase chain reaction ( $q P C R)$ analysis. Total RNA was isolated by homogenizing the femoral heads using the TRIzol ${ }^{\circledR}$ protocol. cDNA was synthesized using the RevertAid $^{\text {TM }}$ First Strand cDNA Synthesis kit (Fermentas, Burlington, ON, Canada) according to the manufacturer's instructions. Samples were analyzed using SYBR-Green ${ }^{\circledR}$ PCR Master mix (DRR820S; Takara Bio, Inc., Shiga, Japan) and an ABI 7300 Real-Time PCR system (Bio-Rad Laboratories, Hercules, CA, USA). The sequences of the primers used for qPCR were as follows: Forward: 5'-TGTAGCCAAAGTCACCTGCATC-3' and reverse: 5'-ACTCGTAATGGAAAGCACAAACC-3' for the $\mathrm{AT}_{1}$ receptor; forward: 5'-ATAAGCCATCA GATAAGCAG TTAG-3' and reverse: 5'-GAGGAAGAGTAGCCACAAGG-3' for the $\mathrm{AT}_{2}$ receptor; forward: 5'-GGA GCATTACCAA GGAGAACTAC-3', and reverse: 5'-AAC TGGAACTGGATG ATGAAGC-3' for ACE; and forward: 5'-GTGCGGGACATC AAGGAGA-3' and reverse: 5'-AGGAAGGAGGGC TGGAAGAG-3' for $\beta$-actin. Relative mRNA expression was quantified using the $2^{-\Delta \Delta \mathrm{Ct}}$ method, in which $\Delta \Delta \mathrm{Ct}=(\mathrm{Ctgene}-\mathrm{Ct} \beta)$ $\mathrm{A} / \mathrm{B} / \mathrm{C}-(\mathrm{Ctgene}-\mathrm{Ct} \beta) \mathrm{N}$. The relative quantities of the $\mathrm{AT}_{1}$ and $\mathrm{AT}_{2}$ receptors and $\mathrm{ACE}$ were normalized to the quantity of the $\beta$-actin transcript in the same sample. All assays were performed in triplicate.

Statistical analysis. All statistical analyses were performed using SPSS 17.0 (SPSS Inc., Chicago, IL, USA). The incidence of ON was compared using the $\chi^{2}$ test or Fisher's exact test. All data are expressed as the mean \pm standard deviation and compared using one way analysis of variance or the Kruskal-Wallis test. $\mathrm{P}<0.05$ was considered to indicate a statistically significant difference.

\section{Results}

Incidence of steroid-induced ON. Five of the 55 rabbits died following MPA injection and were excluded from the experiments. One was in group A, two were in group B and two were in group $\mathrm{C}$. The remaining rabbits were alive until the end of the experiment. ON was not found in group $\mathrm{N}$, whereas three of the 14 rabbits in group A, six of the 13 rabbits in group B and 10 of the 13 rabbits in group $C$ were observed to develop $\mathrm{ON}$. The incidence of $\mathrm{ON}$ in group $\mathrm{C}(77 \%)$ was significantly higher than that in group A $(21 \% ; \mathrm{P}=0.007)$, but not significantly different from that in group $\mathrm{B}(46 \% ; \mathrm{P}=0.226)$. Compared with group $\mathrm{A}$, the incidence of $\mathrm{ON}$ in group $\mathrm{B}$ was found to increase, but there was no significant difference between the two groups $(\mathrm{P}=0.236)$ (Fig. 1).

$A T_{1}$ receptor and $A C E$ protein expression in bone. Immunohistological analysis of the femoral heads showed that the $\mathrm{AT}_{1}$ receptor and $\mathrm{ACE}$ were expressed in the osteoblasts, osteoclasts and bone marrow cells of the bone tissue, but were not expressed in osteocytes (Fig. 2). This finding is consistent with previous studies $(8,21,22)$. Immunostaining for $\mathrm{AT}_{1}$ receptor was observed to increase in group $\mathrm{A}$ and was most significant in group $\mathrm{B}$, compared with group $\mathrm{N}$ (Fig. 2). Quantitative image analysis of $\mathrm{AT}_{1}$ receptor immunostaining revealed an increase in group A compared with group $\mathrm{N}(\mathrm{P}=0.037)$, and an increase in group $\mathrm{B}$ compared with groups $\mathrm{N}$ and $\mathrm{C}(\mathrm{P}=0.004$ and $\mathrm{P}=0.032$, respectively) (Fig. 3). Immunostaining for ACE was highest in group A (Fig. 2). Quantitative image analysis of immunostaining for ACE demonstrated a significant increase in group A compared with groups $\mathrm{N}$ and $\mathrm{C}(\mathrm{P}=0.002$ and $\mathrm{P}=0.037$, respectively), and a significant increase in group $\mathrm{B}$ compared with group $\mathrm{N}$ ( $\mathrm{P}=0.026)$ (Fig. 3).

Western blot analysis revealed a significant increase in $\mathrm{AT}_{1}$ receptor expression in group A compared with group $\mathrm{N}$ $(\mathrm{P}=0.004)$ and in group $\mathrm{B}$ compared with groups $\mathrm{N}$ and $\mathrm{C}$ $(\mathrm{P}<0.001)$. Furthermore, the protein expression of ACE was observed to increase in group A compared with groups $\mathrm{N}$, $\mathrm{B}$ and $\mathrm{C}(\mathrm{P}<0.001, \mathrm{P}=0.023$ and $\mathrm{P}=0.001$, respectively), and significantly increased in groups $\mathrm{B}$ and $\mathrm{C}$ compared with group $\mathrm{N}(\mathrm{P}=0.002$ and $\mathrm{P}=0.041$, respectively) (Fig. 4).

Ang II concentration and ACE activity. The concentration of Ang II in the bone was found to increase in groups A, B and C compared with group $\mathrm{N}(\mathrm{P}=0.001, \mathrm{P}=0.023$ and $\mathrm{P}=0.078$, respectively). The concentration of Ang II in the bone was observed to decline among groups A, B and C; however, these changes were not significant (Table I). The activity of $\mathrm{ACE}$ in the bone of rabbits in group $\mathrm{A}$ was higher than that in groups $\mathrm{N}, \mathrm{B}$ and $\mathrm{C}(\mathrm{P}<0.001, \mathrm{P}=0.002$ and $\mathrm{P}<0.001$, respectively). Furthermore, the activity of ACE in groups B and $\mathrm{C}$ was found to increase compared with group $\mathrm{N}(\mathrm{P}<0.001)$. The concentration of Ang II in the plasma and the activity 

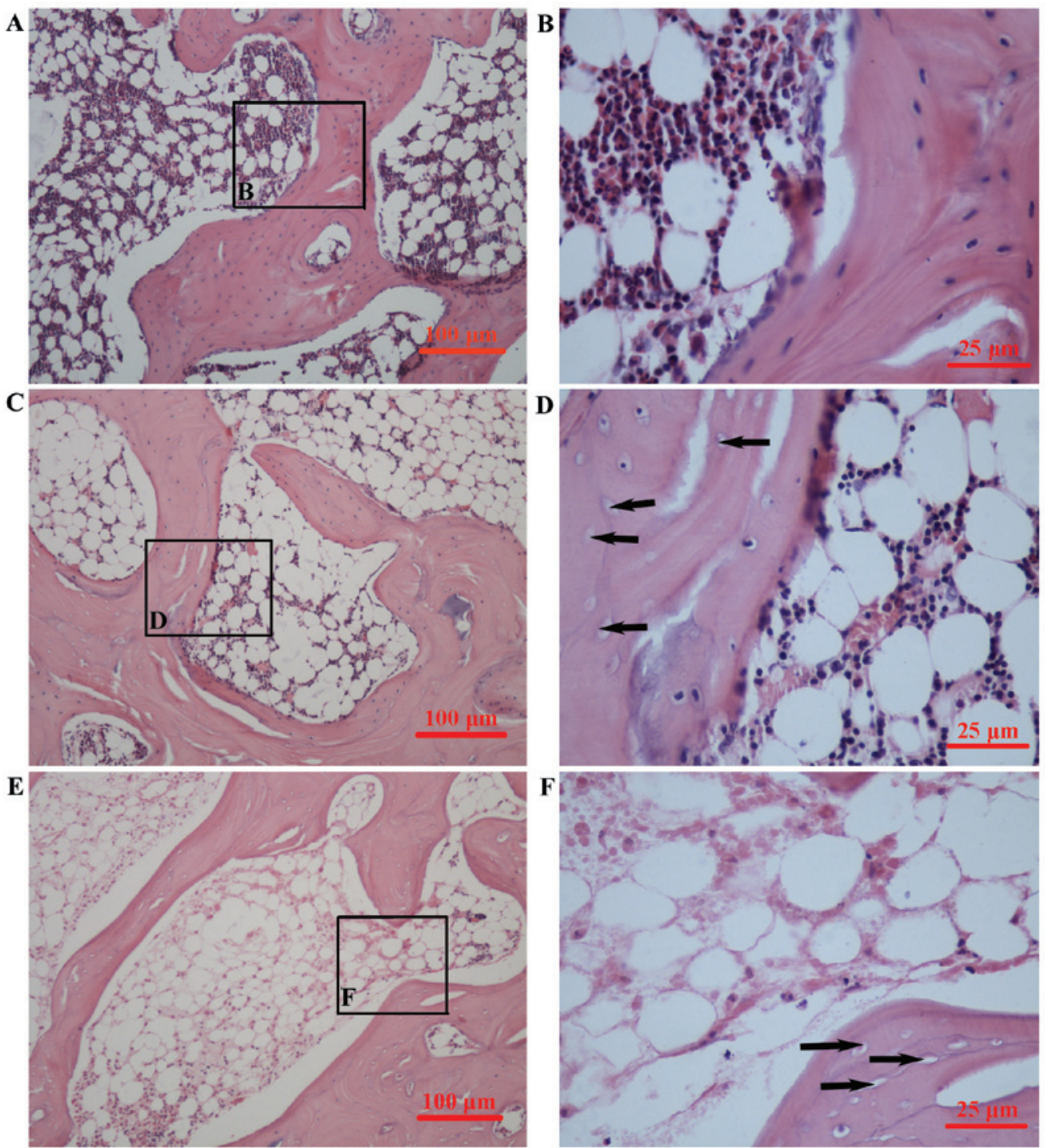

Figure 1. Histological features of ON in rabbits. (A and B) Normal bone tissue harvested from group N showing no ON. (C and D) Normal bone tissue harvested from group A showing empty lacunae containing no osteocytes (arrow) and no bone marrow or fat cell necrosis. (E and F) Osteonecrotic bone tissue harvested from group C. Necrotic trabeculae show pyknosis and empty lacunae (arrow) with marked degeneration of the surrounding bone marrow haematopoietic cells and adipocytes. Stain, hematoxylin and eosin. Magnification, (a, c and e) x100; (b, d and f) x400. ON, osteonecrosis.

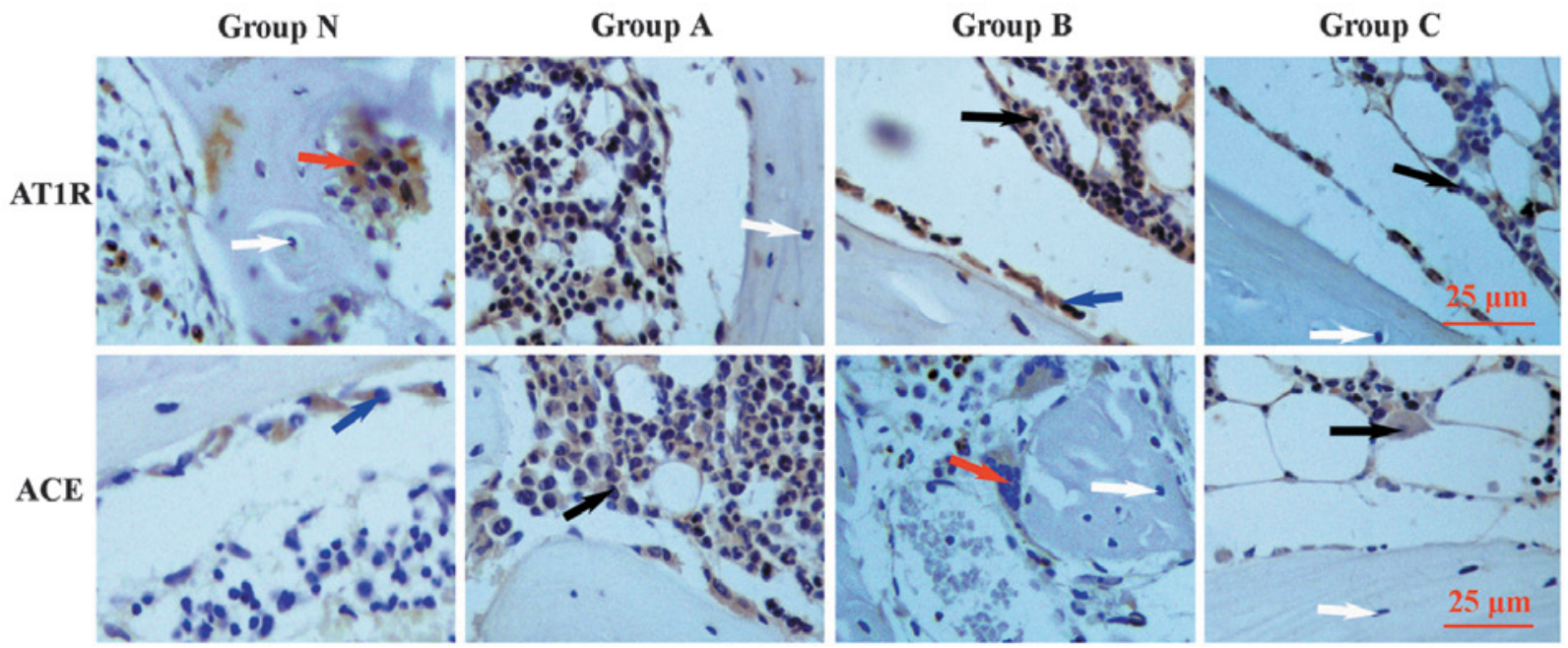

Figure 2. Immunohistochemical staining of the $\mathrm{AT}_{1}$ receptor and $\mathrm{ACE}$ in rabbit femoral heads from groups $\mathrm{N}, \mathrm{A}, \mathrm{B}$ and $\mathrm{C}$. $\mathrm{AT}_{1}$ receptor and $\mathrm{ACE}_{\text {are }}$ expressed in osteoblasts (blue arrows), osteoclasts (red arrows) and bone marrow cells (black arrows), but are not expressed in osteocytes (white arrows). Magnification, $\mathrm{x} 400 . \mathrm{AT}_{1}$, Ang II type 1; ACE, angiotensin converting enzyme. 
Table I. Concentration of Ang II and the activity of ACE in groups N, A, B and C.

\begin{tabular}{lcccc}
\hline Group & $\begin{array}{c}\text { Ang II in bone } \\
(\mathrm{pg} / \mathrm{mg} \text { pro })\end{array}$ & $\begin{array}{c}\text { Ang II in plasma } \\
(\mathrm{pg} / \mathrm{ml})\end{array}$ & $\begin{array}{c}\text { ACE activity in bone } \\
(\mathrm{nmol} / \mathrm{mg} \text { pro/min })\end{array}$ & $\begin{array}{c}\text { ACE activity in serum } \\
(\mathrm{nmol} / \mathrm{ml} / \mathrm{min})\end{array}$ \\
\hline $\mathrm{N}$ & $1.72 \pm 1.09$ & $103.81 \pm 13.81$ & $2.43 \pm 0.57$ & $139.75 \pm 11.33$ \\
$\mathrm{~A}$ & $4.42 \pm 2.27^{\mathrm{a}}$ & $99.90 \pm 23.11$ & $11.92 \pm 2.48^{\mathrm{a}}$ & $151.66 \pm 16.32$ \\
$\mathrm{~B}$ & $3.48 \pm 1.08^{\mathrm{a}}$ & $113.24 \pm 17.75$ & $8.65 \pm 2.46^{\mathrm{a}, \mathrm{b}}$ & $131.92 \pm 18.31$ \\
$\mathrm{C}$ & $3.08 \pm 1.84^{\mathrm{a}}$ & $102.75 \pm 17.34$ & $8.07 \pm 2.53^{\mathrm{a}, \mathrm{b}}$ & $147.70 \pm 19.13$ \\
\hline
\end{tabular}

Values are presented as the mean \pm standard deviation. ${ }^{a} \mathrm{P}<0.05$ vs. group $\mathrm{N}$; ${ }^{b} \mathrm{P}<0.05$ vs. group $\mathrm{A} . \mathrm{n}=10-14$ per group. Pro, protein; Ang II, angiotensin II; ACE, angiotensin converting enzyme.

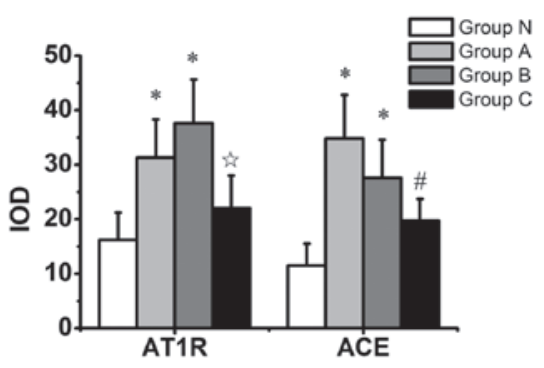

Figure 3. Quantitative analysis of the intensity of the immunostaining for the $\mathrm{AT}_{1}$ receptor and $\mathrm{ACE}$ in rabbit femoral heads from groups $\mathrm{N}, \mathrm{A}, \mathrm{B}$ and $\mathrm{C}$. ${ }^{*} \mathrm{P}<0.05$ vs. group $\mathrm{N} ;{ }^{\text {}} \mathrm{P}<0.05$ vs. group $\mathrm{A}$ and ${ }^{\text {t }} \mathrm{P}<0.05$ vs. group $\mathrm{B}$. IOD, integrated optical density; $\mathrm{AT}_{1}$, Ang II type 1; ACE, angiotensin converting enzyme.
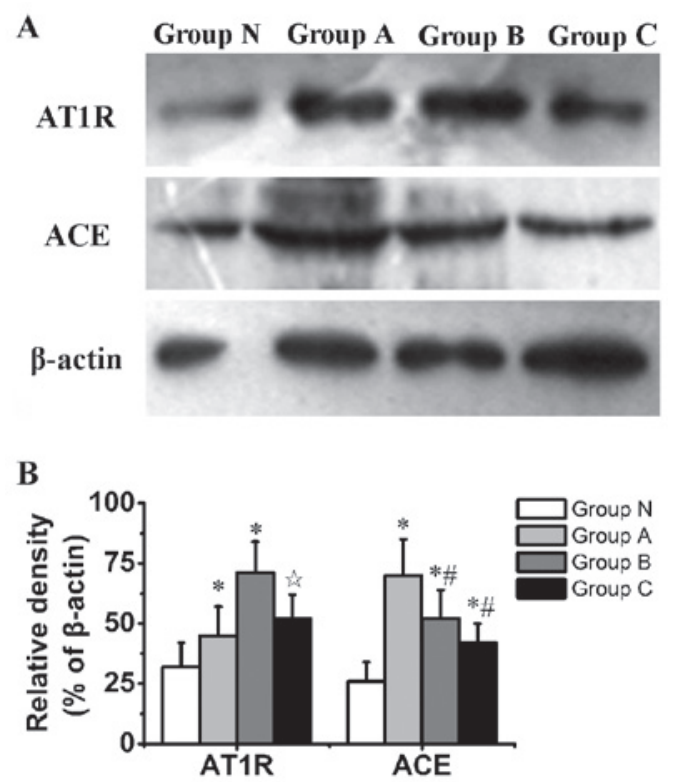

Figure 4. Western blot analysis of $\mathrm{AT}_{1}$ receptor and $\mathrm{ACE}$ expression in rabbit femoral heads from groups $\mathrm{N}, \mathrm{A}, \mathrm{B}$ and $\mathrm{C}$ ( $\mathrm{n}=6$ in each group). (A) Western blot analysis. (B) Quantification of $\mathrm{AT}_{1}$ receptor and $\mathrm{ACE}$ protein expression using densitometry and normalized to that of $\beta$-actin. ${ }^{*} \mathrm{P}<0.05$ vs. group $\mathrm{N}$; ${ }^{\text {" }} \mathrm{P}<0.05$ vs. group $\mathrm{A}$ and ${ }^{\text {到 }} \mathrm{P}<0.05$ vs. group $\mathrm{B} . \mathrm{AT}_{1}$, Ang II type $1 ; \mathrm{ACE}$, angiotensin converting enzyme.

of ACE in the serum were not observed to differ significantly among the groups (Table I). These changes in local and systemic RAS activity are similar to those observed by

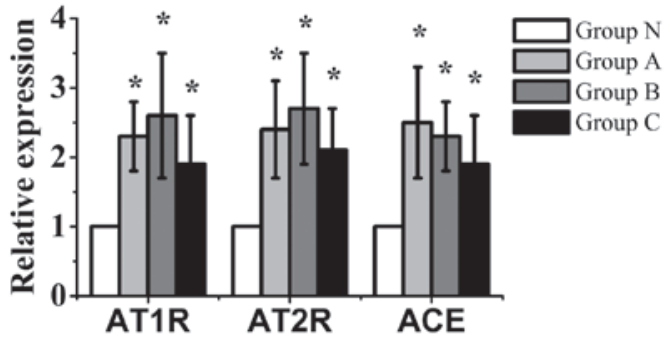

Figure 5. $\mathrm{ACE}$ and $\mathrm{AT}_{1}$ and $\mathrm{AT}_{2}$ receptor mRNA expression in rabbit femoral heads in groups $\mathrm{N}, \mathrm{A}, \mathrm{B}$ and $\mathrm{C}\left(\mathrm{n}=10\right.$ each group). ${ }^{*} \mathrm{P}<0.05$ vs. group $\mathrm{N}$. $\mathrm{AT}_{1}$, Ang II type 1; $\mathrm{AT}_{2}$, Ang II type 2; ACE, angiotensin converting enzyme.

Mitani et al (19), who found that cholesterol increased local tissue ACE activity but not serum ACE activity in rabbits, suggesting that the systemic RAS may be more stable than the local RAS.

mRNA expression of $A T_{1}$ and $A T_{2}$ receptors and $A C E$ in the bone. The mRNA expression of $\mathrm{AT}_{1}$ and $\mathrm{AT}_{2}$ receptors and $\mathrm{ACE}$ in groups $\mathrm{A}, \mathrm{B}$ and $\mathrm{C}$ was significantly higher than that in group $\mathrm{N}(\mathrm{P}<0.05)$. The mRNA levels of the $\mathrm{AT}_{1}$ and $\mathrm{AT}_{2}$ receptors in group $\mathrm{B}$ were the highest of the 4 groups. Furthermore, the mRNA expression of ACE in group A was the highest of the 4 groups (Fig. 5).

\section{Discussion}

In the present study, ON was first observed one week subsequent to MPA injection and was most significant three weeks following injection. The incidence of ON was $77 \%$ three weeks following MPA administration, which was similar to that observed in the study by Iwakiri et al (17), in which the incidence of ON was $83 \%$ three weeks subsequent to steroid injection. In the present study, the expression of Ang II, ACE, and the $\mathrm{AT}_{1}$ and $\mathrm{AT}_{2}$ receptors significantly increased one week following MPA administration, concurrent with the onset of $\mathrm{ON}$ in this animal model. Moreover, the expression of Ang II and ACE was highest one week subsequent to steroid administration and the expression of the $\mathrm{AT}_{1}$ and $\mathrm{AT}_{2}$ receptors was highest two weeks following MPA administration. These changes in expression following MPA injection, precede the time at which ON occurs most significantly in this animal model, which is three weeks. This suggests that ON is strongly 


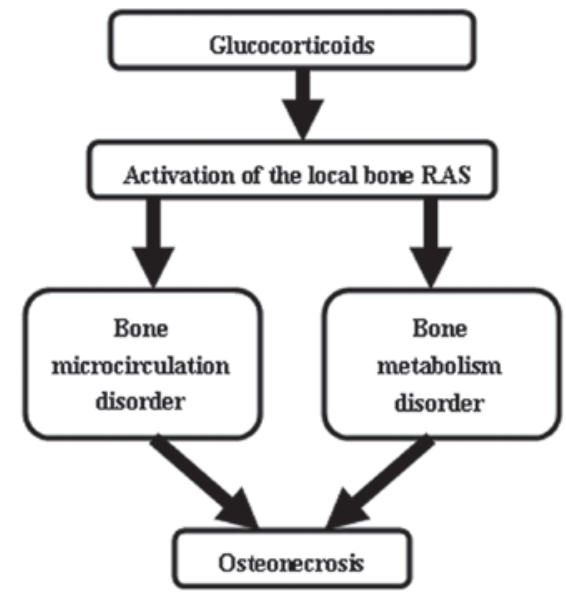

Figure 6. Schematic representation of the potential mechanisms underlying ON. Glucocorticoids activate the local bone RAS, which induces bone microcirculation and bone metabolism disorders generating an environment that favours the development of ON. ON, osteonecrosis; RAS, renin-angiotensin system.

associated with changes in the expression of components of the RAS, including Ang II, ACE, and the $\mathrm{AT}_{1}$ and $\mathrm{AT}_{2}$ receptors.

Although the precise mechanism underlying the pathogenesis of steroid-induced ON is yet to be elucidated, studies of the pathophysiology of ON have shown that GCs induce ischemia of the femoral head and an imbalance in osteoblast and osteoclast activity, leading to $\mathrm{ON}$, which is highly likely to underlie the pathogenesis of steroid-induced ON (23-25). Previous studies have shown that the activation of the local bone RAS induces metabolic bone disorders $(7,9,26)$ and impairs bone microcirculation (27). In the present study, the GC MP was found to activate the local bone RAS, which is similar to the effect of GCs on the local RAS reported in other tissues $(13,16)$. Therefore, steroid-induced ON may be closely associated with the local bone RAS in rabbits.

In the present study, two potential mechanisms were hypothesized to underlie the activation of the local bone RAS and induce ON following steroid administration (Fig. 6). The first possible mechanism involves a disruption in the microcirculation of bone. Ang II is one of the most potent microvascular vasoactive agents (28), and leads to vessel contraction and decreased blood supply of the femoral head. Ang II induces the production of adhesion molecules, chemokines and inflammatory cytokines, including vascular cell adhesion molecule-1, intercellular adhesion molecule-1, E-selectin, monocyte chemoattractant protein-1, interleukin-6, interleukin-8 and tumor necrosis factor- $\alpha$ in endothelial cells (29). These molecules induce endothelial cell dysfunction, abnormal blood coagulation and thrombi formation, which may lead to ischemia of the femoral head (30). Ang II upregulates NADPH oxidase components, thereby enhancing the production of ROS in the microcirculation of the bone (31). ROS are potent interand intracellular second messengers, which mediate vessel inflammation (32). Elevated ROS levels induce growth arrest and increase the rate of senescence and apoptosis in endothelial cells. Ang II also stimulates the expression of plasminogen activator inhibitor-1 (33), which alters homeostatic mechanisms that balance thrombosis with fibrinolysis and lead to hypercoagulability of the bone microcirculation.
The activation of the local RAS in the bone microcirculation may lead to vessel contraction, vascular inflammation, endothelial cell dysfunction and hypercoagulability of the bone microcirculation, which decrease the blood supply and ischemia of the femoral head. These alterations induce a pathological condition increasing the risk of $\mathrm{ON}$.

The second possible mechanism underlying the pathogenesis of $\mathrm{ON}$ involves altered bone metabolism. In the local milieu of the bone, two major types of cells, osteoblasts and osteoclasts, coordinately resorb and form the bone matrix, which conserves the bone architecture and mass during adulthood (34). However, the balance between osteoblasts and osteoclasts is disturbed by the activation of the local bone RAS. Previous studies have shown that Ang II suppresses osteoblastic cell differentiation and bone formation, and decreases calcium uptake into the bone $(9,10)$. In addition, Ang II activates osteoclasts and stimulates bone resorption (35). In a clinical study, patients treated with an ACE inhibitor exhibited increased bone mineral density and reduced fracture risk (11). Therefore, the activation of the local bone RAS may suppress bone formation and stimulate bone resorption, causing a bone metabolism disorder through altering the balance between bone formation and bone resorption, increasing the risk of $\mathrm{ON}$ development and impairing $\mathrm{ON}$ repair.

In summary, GCs may activate the local bone RAS, which may impair bone microcirculation and bone metabolism. These effects, in conjunction with numerous other factors, including alterations in lipid metabolism and intraosseous hypertension, may induce $\mathrm{ON}$.

In the present study, the expression of Ang II, ACE, and the $\mathrm{AT}_{1}$ and $\mathrm{AT}_{2}$ receptors significantly increased one week following MPA administration, and the concentration of Ang II and the activity of ACE in the bone were highest one week subsequent to MPA injection. However, the expression of the $\mathrm{AT}_{1}$ and $\mathrm{AT}_{2}$ receptors was greatest two weeks following MPA injection potentially due to the overproduction of Ang II one week following MPA injection. Thus, Ang II may stimulate the expression of the $\mathrm{AT}_{1}$ and $\mathrm{AT}_{2}$ receptors, which has been reported in a previous study (36). Therefore, the administration of ACE inhibitor (ACEI) or angiotensin receptor blocker $(A R B)$ in rabbits may inhibit the GC-induced activation of the local bone RAS, which may represent a preventive treatment for steroid-induced $\mathrm{ON}$. This will be investigated in our future studies.

The present study has certain limitations. The data show that the expression of the components of the local bone RAS, including Ang II, ACE and the $\mathrm{AT}_{1}$ and $\mathrm{AT}_{2}$ receptors were enhanced by MPA in the femoral head, but the precise role of the local bone RAS in the development of $\mathrm{ON}$ requires further investigation. Thus, future studies will be performed in order to demonstrate the interrelation between the activation of local bone RAS and the development of ON, as well as the effect of ACEI or ARB on preventing steroid-induced ON.

In conclusion, activation of the local bone RAS may not be the sole cause of steroid-induced ON, and the precise role of the local bone RAS in the pathogenesis of $\mathrm{ON}$ requires further investigation. However, the present study has contributed to an enhanced understanding of the molecular processes underlying ON. Furthermore, these findings suggest the possibility 
of preventive approaches to steroid-induced ON through blocking the activation of the local bone RAS.

\section{Acknowledgements}

This study was partially supported by a grant from the National Natural Science Foundation of China (grant no. 81101337). The authors would like to thank the pathologists Mr. Xiaoge Zhao and Mr. Gang Cui from the Medical College of Xi'an Jiaotong University (China) for their contributions.

\section{References}

1. Miyanishi K, Yamamoto T, Irisa T, et al: Bone marrow fat cell enlargement and a rise in intraosseous pressure in steroid-treated rabbits with osteonecrosis. Bone 30: 185-190, 2002

2. Ichiseki T, Ueda Y, Katsuda S, Kitamura K, Kaneuji A and Matsumoto T: Oxidative stress by glutathione depletion induces osteonecrosis in rats. Rheumatology (Oxford) 45: 287-290, 2006

3. Calder JD, Buttery L, Revell PA, Pearse M and Polak JM: Apoptosis - a significant cause of bone cell death in osteonecrosis of the femoral head. J Bone Joint Surg Br 86: 1209-1213, 2004.

4. Ichiseki T, Matsumoto T, Nishino M, Kaneuji A and Katsuda S: Oxidative stress and vascular permeability in steroid-induced osteonecrosis model. J Orthop Sci 9: 509-515, 2004.

5. Kabata T, Kubo T, Matsumoto T, et al: Onset of steroid-induced osteonecrosis in rabbits and its relationship to hyperlipaemia and increased free fatty acids. Rheumatology (Oxford) 44: 1233-1237, 2005

6. Paul M, Poyan Mehr AP and Kreutz R: Physiology of local renin-angiotensin systems. Physiol Rev 86: 747-803, 2006.

7. Asaba Y, Ito M, Fumoto T, et al: Activation of renin-angiotensin system induces osteoporosis independently of hypertension. J Bone Miner Res 24: 241-250, 2009.

8. Garcia P, Schwenzer S, Slotta JE, et al: Inhibition of angiotensin-converting enzyme stimulates fracture healing and periosteal callus formation - role of a local renin-angiotensin system. Br J Pharmacol 159: 1672-1680, 2010.

9. Schurman SJ, Bergstrom WH, Shoemaker LR and Welch TR: Angiotensin II reduces calcium uptake into bone. Pediatr Nephrol 19: 33-35, 2004.

10. Hagiwara H, Hiruma Y, Inoue A, Yamaguchi A and Hirose S: Deceleration by angiotensin II of the differentiation and bone formation of rat calvarial osteoblastic cells. J Endocrinol 156 : 543-550, 1998.

11. Lynn H, Kwok T, Wong SY, Woo J and Leung PC: Angiotensin converting enzyme inhibitor use is associated with higher bone mineral density in elderly Chinese. Bone 38: 584-588, 2006

12. Marchesi C, Paradis P and Schiffrin EL: Role of the renin-angiotensin system in vascular inflammation. Trends Pharmacol Sci 29: 367-374, 2008

13. Fishel RS, Eisenberg S, Shai SY, Redden RA, Bernstein KE and Berk BC: Glucocorticoids induce angiotensin-converting enzyme expression in vascular smooth muscle. Hypertension 25: 343-349, 1995.

14. Barreto-Chaves M, Anéas I and Krieger J: Glucocorticoid regulation of angiotensin-converting enzyme in primary culture of adult cardiac fibroblasts. Am J Physiol Regul Integr Comp Physiol 280: R25-R32, 2001.

15. Mendelsohn FA, Lloyd CJ, Kachel C and Funder JW: Induction by glucocorticoids of angiotensin-converting enzyme production from bovine endothelial cells in culture and rat lung in vivo. J Clin Invest 70: 684-692, 1982.
16. Sato A, Suzuki H, Nakazato Y, Shibata H, Inagami T and Saruta T: Increased expression of vascular angiotensin II type $1 \mathrm{~A}$ receptor gene in glucocorticoid-induced hypertension. J Hypertens 12: 511-516, 1994.

17. Iwakiri K, Oda Y, Kaneshiro Y, et al: Effect of simvastatin on steroid-induced osteonecrosis evidenced by the serum lipid level and hepatic cytochrome P4503A in a rabbit model. J Orthop Sci 13: 463-468, 2008.

18. Kuribayashi M, Fujioka M, Takahashi KA, et al: Vitamin E prevents steroid-induced osteonecrosis in rabbits. Acta Orthop 81: 154-160, 2010.

19. Mitani H, Bandoh T, Ishikawa J, Kimura M, Totsuka T and Hayashi S: Inhibitory effects of fluvastatin, a new HMG-CoA reductase inhibitor, on the increase in vascular ACE activity in cholesterol-fed rabbits. Br J Pharmacol 119: 1269-1275, 1996.

20. Liu BC, Gao J, Li Q and Xu LM: Albumin caused the increasing production of angiotensin II due to the dysregulation of ACE/ACE2 expression in HK2 cells. Clin Chim Acta 403: 23-30, 2009.

21. Izu Y, Mizoguchi F, Kawamata A, et al: Angiotensin II type 2 receptor blockade increases bone mass. J Biol Chem 284: 4857-4864, 2009

22. Haznedaroglu IC and Oztürk MA: Towards the understanding of the local hematopoietic bone marrow renin-angiotensin system. Int J Biochem Cell Biol 35: 867-880, 2003.

23. Powell C, Chang $C$ and Gershwin ME: Current concepts on the pathogenesis and natural history of steroid-induced osteonecrosis. Clin Rev Allergy Immunol 41: 102-113, 2011.

24. Wang L, Wang N, Li M and Wang KZ: To investigate the role of the nervous system of bone in steroid-induced osteonecrosis in rabbits. Osteoporos Int 21: 2057-2066, 2010.

25. Drescher W, Weigert KP, Bunger MH, Ingerslev J, Bünger C and Hansen ES: Femoral head blood flow reduction and hypercoagulability under $24 \mathrm{~h}$ megadose steroid treatment in pigs. J Orthop Res 22: 501-508, 2004.

26. Sabanai K, Tsutsui M, Sakai A, et al: Genetic disruption of all NO synthase isoforms enhances BMD and bone turnover in mice in vivo: involvement of the renin-angiotensin system. J Bone Miner Res 23: 633-643, 2008.

27. Fukuda D and Sata M: Role of bone marrow renin-angiotensin system in the pathogenesis of atherosclerosis. Pharmacol Ther 118: 268-276, 2008.

28. Wassmann S and Nickenig G: Pathophysiological regulation of the AT1-receptor and implications for vascular disease. J Hypertens Suppl 24: S15-S21, 2006.

29. Pueyo ME, Gonzalez W, Nicoletti A, Savoie F, Arnal JF and Michel JB: Angiotensin II stimulates endothelial vascular cell adhesion molecule-1 via nuclear factor-kappaB activation induced by intracellular oxidative stress. Arterioscler Thromb Vasc Biol 20: 645-651, 2000.

30. Harrison DG: Cellular and molecular mechanisms of endothelial cell dysfunction. J Clin Invest 100: 2153-2157, 1997.

31. Yao EH, Fukuda N, Matsumoto T, et al: Losartan improves the impaired function of endothelial progenitor cells in hypertension via an antioxidant effect. Hypertens Res 30: 1119-1128, 2007.

32. Ohtsu H, Frank GD, Utsunomiya $H$ and Eguchi S: Redox-dependent protein kinase regulation by angiotensin II: mechanistic insights and its pathophysiology. Antioxid Redox Signal 7: 1315-1326, 2005.

33. Vaughan DE, Lazos SA and Tong K: Angiotensin II regulates the expression of plasminogen activator inhibitor-1 in cultured endothelial cells. A potential link between the renin-angiotensin system and thrombosis. J Clin Invest 95: 995-1001, 1995.

34. Zhao C, Irie N, Takada Y, et al: Bidirectional ephrinB2-EphB4 signaling controls bone homeostasis. Cell Metab 4: 111-121, 2006.

35. Shimizu H, Nakagami H, Osako MK, et al: Angiotensin II accelerates osteoporosis by activating osteoclasts. FASEB J 22: 2465-2475, 2008.

36. Liu JJ, Li DL, Zhou J, et al: Acetylcholine prevents angiotensin II-induced oxidative stress and apoptosis in H9c2 cells. Apoptosis 16: 94-103, 2011 